\title{
Pedagogical Competence in Pre-Service Biology Teacher through Lesson Study
}

\author{
Ina Setiawati ${ }^{1}$, Anna Fitri Hindriana ${ }^{2}$, Rahma Widiantie ${ }^{3}$, Ilah nurlaelah ${ }^{4}$, Lilis \\ Lismaya $^{5}$ \\ ${ }^{12345}$ Biology Education Study Program, FKIP, Kuningan University \\ Email : ina.setiawati@uniku.ac.id
}

\begin{abstract}
This study aims to analyze the pedagogical competence in pre-service biology teacher. pre-service biology teacher is usually trained to manage the learning process through micro-teaching activities. learning exercises through micro-teaching are important to help train the pedagogical competence in pre-service biology teacher. One way that micro-teaching can develop the pedagogical competency in pre-service biology teacher to the maximum is by integrating it with the lesson study. This study uses action research. Lesson Study research was carried out in 2 cycles in three stages each cycle, namely Plan (development of lesson plans, media and teaching materials), Do (implementation of lesson study) and See (continuous reflection.). The results of the study can be concluded that the pedagogical competency in pre-service biology teacher through lesson study has increased in the moderate category. In the indicator of the ability to plan and the ability to carry out learning there is an increase from the level of partial competence to competence, and the ability to evaluate there is an increase from needing to improve to being competent. This explains that the implementation of lesson study has a positive impact on improving the pedagogical ability and professionalism in pre-service biology teacher at FKIP, Kuningan University.
\end{abstract}

Keywords: Micro-teaching; lesson study; competence; pedagogical; pre-service biology teacher

\section{Introduction}

Pre-service teacher are prospective educators who have an important role in shaping and determining the quality of human resources in the future. One of the competencies that can be trained to Pre-service teacher is pedagogical competence. Pedagogical competence is an important competence that must be mastered by Pre-service teacher because this pedagogical competence is the primary ability that determines the implementation of learning to achieve learning objectives. This pedagogic ability is related to the study of the arts and teaching science (Arends, 2008). Teachers need to understand pedagogical competence in managing learning, which includes; learning design, learning implementation, learning evaluation, and student development according to their potential (Mulyasa, 2013). Pre-service teacher are usually trained to manage the learning process through micro-teaching learning simulation activities. When a pre-service teacher interacts with his partners in micro-teaching learning, pre-service teacher will learn from each other. This process will help build learning objectives, design lesson plans, and analyze the development of their professional skills (Donnelly, 2007; Nurlaelah, 
2013). Learning exercises through micro-teaching are important to help train the pedagogical competence in pre-service biology teacher. One way that micro-teaching can develop the pedagogical abilities of prospective teacher students maximally is by integrating it with the Lesson Study program (Hidayat, 2016). Lesson study is oriented towards improving the quality of learning gradually by learning from experiences of yourself and others in carrying out learning activities (Widodo, et, al, 2009).

Increasing pedagogical competence, especially the ability to plan lessons and the ability to implement learning can be accomplished through Lesson Study activities. Lesson Study is an activity that has great potential in improving the professional quality of teachers which has an impact on improving the quality of the process and learning outcomes and creating a process of interaction between various parties. (Putri, 2018). This study attempts to look at the pedagogical competence profile of pre-service teacher during micro-teaching through the lesson study. Based on previous research (Setiawati, et al, 2018) the pedagogical competence of pre-service biology teacher is on average at the level of partial competence in designing learning. At this level of partial competence, pre-service teacher has been able to design learning quite well, the completeness of the lesson plans is complete even though the information on each component is still limited and does not match the characteristics of the learning model The intention is that through this lesson study pre-service teacher will be able to correct shortages in each simulation cycle.

\section{Method}

This study uses action research. The Lesson Study research was carried out in 2 cycles in three stages each cycle, namely Plan (development of lesson plans, media, and teaching materials), Do (implementation of lesson study), and See (continuous reflection.). After cycle 1 , an evaluation of lesson study activities is carried out to continue to cycle 2 . The population in the study were all 6th-semester students of the Biology Education Study Program, FKIP, Kuningan University. The sampling technique used purposive sampling, namely 1 group of 6thsemester students who took microteaching courses. Data collection techniques using observation techniques and recording microteaching activities. The instruments in this study were a pedagogical competence assessment sheet and a questionnaire. The data obtained will be analyzed quantitatively and qualitatively. Data from the calculation of pedagogical competence (designing lesson plans, implementing learning, and evaluating) are processed in the form of scores and also interpreted according to the level specified in the assessment rubric (superior, competent, partially competent, needs improvement). Value processing is as follows:

$$
\text { Value }=\frac{\text { number of scores obtained }}{\text { total score count of all criteria }} \times 100
$$

Table 1. Pedagogical Value Conversion

\begin{tabular}{ccc}
\hline Average & Score & Pedagogical Competency Level \\
\hline $3,6-4$ & $90-100$ & Excellent. \\
$2,6-3,5$ & $75-89$ & Competent \\
$2-2,5$ & $50-74$ & Partially Competent \\
$1-1,9$ & $25-49$ & Needs Improvement \\
\hline
\end{tabular}

The increase in pedagogic ability is also calculated using gain calculations. The formula used is as follows: 


$$
<\text { gain }>=\frac{\text { score post tes }- \text { score pretes }}{\text { score maximum }- \text { score pretes }}
$$

The results of the gain calculation are interpreted using the gain index $<\mathrm{g}>$ according to the Meltzer (2002) classification according to Table 2 below:

Table 2. Gain Criteria

\begin{tabular}{cc}
\hline Index Gain & Interpretation Gain \\
\hline $\mathrm{g}>0,7$ & High \\
$0,3>\mathrm{g}>0,7$ & Moderate \\
$\mathrm{g} \leq 03$ & Low \\
\hline
\end{tabular}

\section{Result and Discussion}

Lesson study activity is a model of competency development for pre-service teacher, through the spirit of togetherness trying to improve the quality of learning. Pedagogical competence of students is assessed using instruments of pedagogical competence assessment sheet with rubric. According to Hindriana (2018) rubric contains dimensions that contain the criteria that must be achieved by pre-service teacher, as well as a scale that explains the acquisition of performance that must be achieved. In this lesson study activity, microteaching lecturers have an important role in facilitating activities and fostering pre-service teacher, so that pre-service teacher can more easily receive suggestions/criticism to improve the quality of learning. The lesson study in this study is a cyclic pattern consisting of:

a. Stage Plan (Scheduling \& Planning), in this stage preparation of lesson study on microteaching learning, is carried out. Usually carried out for 1-3 x initial meeting. Students and lecturers coordinate to plan the making of lesson plan (RPP) where the stages include; determining the topic/teaching material, the design of learning models, the design of ICTbased learning media, worksheets, evaluation instruments to be used in learning, and determining the teaching schedule for all students who practice learning

b. Stage Do (Teaching \& Observation), at this stage lecturers and other practitioners who do not appear to serve as learning observers, where the observer's task is to observe learning using the LS instrument that has been provided. So that when the practical student appears to perform a learning simulation, other practitioners also help observe to evaluate the implementation similar to what is done by the lecturer. After a practitioner appears, the practitioner will receive suggestions/criticism not only from the supervisor but also from peers. At this stage, the practitioner who acts as an observer is given a copy of the lesson plan, the observer is not allowed to interact with learning activities, but the observer is allowed to go around in the class, the observer can communicate with students if needed. Observers can record everything that is observed, the results of these reviewers can be used for their improvement when they change roles to become practitioners who appear in microteaching.

c. Stage See (Reflecting), this stage is an important stage in the lesson study, where the lecturer directly leads this reflection activity in the form of a panel discussion. In this activity, the observer and the lecturer convey the results of their observations to the practitioner who appears to communicate the advantages and disadvantages of the implementation of learning carried out by the practitioner who performs microteaching. 
Submission of the results of observations and analysis is conveyed in a way that is not offensive so as not to discourage student teacher candidates. This reflection activity is carried out openly and thoroughly, covering all stages of the learning process so that it can be useful and comprehensive positive input (Rejeki, et, al, 2018).

The results of the analysis from the lecturers and observers of the practitioners will be material for improvement for the next lesson. Through this reflection activity, it can improve the quality of the implementation of practical learning following the principle of continuous quality improvement. The quality of learning that is observed is directed at training the pedagogical abilities of pre-service teacher. There is an increase in the pedagogical competence of pre-service teacher through lesson study activities with 2 cycles as follows:

Table 3. Pedagogical Competencies

\begin{tabular}{lcccccc}
\hline $\begin{array}{l}\text { Pedagogical } \\
\text { Competencies }\end{array}$ & Value & Level & LS Cycle 1 & \multicolumn{2}{c}{ LS Cycle 2 } \\
Value & Level & Value & Level \\
\hline $\begin{array}{l}\text { 1. Ability to plan learning } \\
\text { 2. Ability to Carry out } \\
\text { learning }\end{array}$ & 54.86 & $\begin{array}{c}\text { Partial } \\
\text { Competent } \\
\text { Partial }\end{array}$ & 70.49 & $\begin{array}{c}\text { Partial } \\
\text { Competent } \\
\text { Partial }\end{array}$ & 84.38 & Competent \\
$\begin{array}{l}\text { 3. Ability to evaluate } \\
\text { learning }\end{array}$ & 66.67 & $\begin{array}{c}\text { Competent } \\
\text { Need }\end{array}$ & 73.61 & $\begin{array}{c}\text { Competent } \\
\text { Partial }\end{array}$ & 85.56 & Competent \\
improvement & 61.46 & Competent & 82.29 & Competent \\
Average competencies & $\mathbf{5 5 . 4 4}$ & & $\mathbf{6 8 . 5 2}$ & & $\mathbf{8 4 . 0 7}$ & \\
\hline
\end{tabular}

Based on Table 3, it can be seen that the pedagogical competency level of pre-service biology teacher has increased from the competent level partially to becoming competent. Increased levels were achieved in all indicators of pedagogical competence, namely; ability to plan, carry out/implement, and evaluate learning. The ability to design learning at the competent level explains that students who practice can expand lesson plans completely, systematically, precisely according to the characteristics of the material and students and according to the systematics determined by the 2013 curriculum.

The ability to carry out learning at the competent level, meaning that the student is able to open learning by attracting attention and motivating students to learn, is skilled in asking questions, is able to carry out a learning model that is in accordance with the syntax of a model that helps students train scientific skills and is able to act as a facilitator who master the subject matter quite well. The ability to evaluate at the competent level explains that students are able to develop authentic instruments in accordance with learning objectives, materials and learning models that train students' high-level cognitive. Although there are still some shortcomings / incomplete, but have been able to try to implement proper assessment techniques. To see more clearly the improvement of each indicator pedagogic competence is described in the following figure and table: 


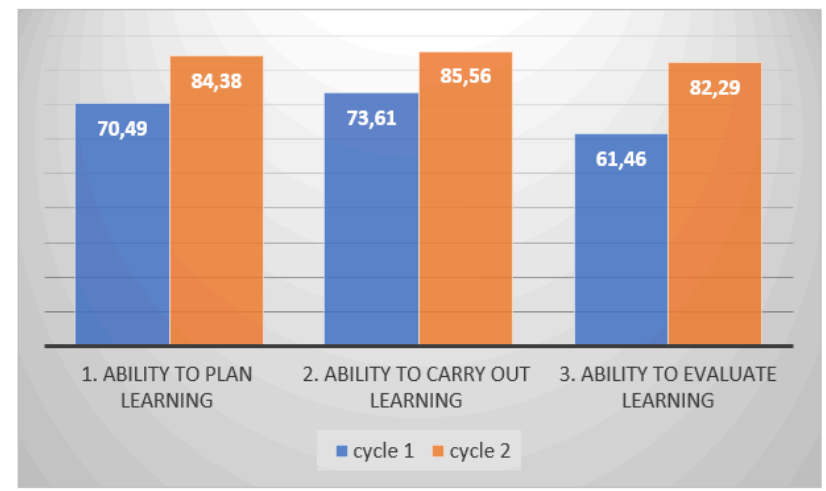

Fig 1. Pedagogical Abilities

Table 4. Pedagogical Enhancement

\begin{tabular}{lcccc}
\hline Pedagogical Competence & $\begin{array}{c}\text { Score } \\
\text { Preliminary }\end{array}$ & $\begin{array}{c}\text { Score } \\
\text { Final }\end{array}$ & Gain & Criteria \\
\hline 1. Ability to plan learning & 2,19 & 3,37 & 0.65 & Moderate \\
2. Ability to Carry out learning & 2,66 & 3,42 & 0.56 & Moderate \\
3. Ability to evaluate learning & 1,79 & 3,29 & 0.67 & Moderate \\
\hline
\end{tabular}

Based on table 4, The gain is calculated for the pedagogical competence of pre-service biology teacher who do microteaching through lesson study, it appears that there is an increase in moderate characteristics for each indicator of the pedagogical competence. Increased pedagogical competence which includes the ability to plan, implement and evaluate in the facilitation of lesson study activities, because through the implementation of this lesson study the role of pre-service biology can act as teachers who carry out learning and become observers who observe other teachers at other times. This changing of roles creates mutual understanding and support among student teacher candidates and effectively improves the quality of the learning process in microteaching simulation activities.

The ability of pre-service biology teacher in designing lesson plans increased with a gain value of 0.65 (moderate), This increase was due to the lesson study model, pre-service biology teacher carry out collaborative learning planning between pre-service biology teacher and Lecturer, so that lesson planning is carried out as detailed and as maximally as possible by considering the characteristics of the material, student characteristics, infrastructure, learning media, strategies/models/methods to be used, and time allocation. The activity of designing learning that is carried out collaboratively causes pre-service teacher to feel motivated and confident in carrying out learning in class. (Handayani, et, al, 2015).

One of the success factors of the teaching and learning process is determined by how the teacher manages the class when teaching, so it requires a mature learning design in the form of a systematic lesson plan so that it makes it easier for students to apply the right strategies/models/method in teaching subject matter. Another effect of the integration of good teaching theory and practice will have an impact on the process of evaluating optimal student learning outcomes (Rejeki, et, al, 2018). This lesson study not only trains student teacher candidates to design learning but is able to carry out learning and evaluate optimal learning. This can be seen in table 4 . Which explains that the average value of each pedagogic competency indicator that has increased is in the moderate category. 
The ability of pre-service teacher in carrying out learning has also increased with a gain value of 0.56 (moderate). After the student is able to make a good lesson plan (RPP), it is hoped that the student will be able to carry out the learning according to the scenario well too. Students practice being used to seeing the suitability of the lesson plans with the implementation of their peers when they act as observers during lesson study. This provides real experiences for them to be able to carry out systematic learning and according to the scenario. This is in line with the opinion of Fikri (2014) which explains that lesson study can encourage the formation of a learning community that is consistent and systematic in terms of self-improvement, expanding basic knowledge in learning (Fikri, 2014).

Expansion of knowledge in the learning process through the implementation of lesson study helps develop professional competence in pre-service teacher (Copriady, 2013). Pedagogical competencies of teachers seen from aspects of knowledge influenced by training. Pre-service teachers are just like teachers who of course need continuous training to train the application of models or methods or techniques or learning strategies, the use of information technology and learning media so that they can improve their pedagogical competencies (Setiawati, et, al, 2020).

\section{Conclusion}

The pedagogical competence of pre-service biology teacher through lesson study has increased in the moderate category. In the indicator of the ability to plan learning and carry out learning, it has increased from a partial competent level to a competent level, while the ability to evaluate has increased from a level that needs to be improved to a competent level.

\section{References}

[1] Arends, Richard I. (2008). Learning to Teach: Belajar untuk Mengajar, Ed 7 Jilid 1 dan 2. Yogyakarta; Pustaka Pelajar

[2] Copriady, J. (2013). The Implementation Of Lesson Study Programme For Developing Professionalism In Teaching Profession. Published by Canadian Center of Science and Education. Asian Social Science. Vol 9 (12): 176-186

[3] Donnelly. (2007). Perveived impact of peer observation of teaching in higher education. international journal of Teaching and learning in Higher Education, 19(2) 117-129

[4] Fikri, K. (2014). Implementasi Lesson Study Dalam Membentuk Learning Community di Program Studi Pendidikan Biologi. Prosiding Seminar Nasional Pendidikan dan SAINS. Program Studi Pendidikan Matematika FKIP Universitas Jember, 16 Maret 2014.

[5] Handayani Rif'ati Dina, Agung Ryskiadi, Ali Machrus, dan Rifan Acik. (2015). Penerapan Lesson Study Untuk Meningkatan Kemampuan Mengajar Mahasiswa Calon Guru Fisika. Jurnal Pengajaran MIPA, Volume 20, Nomor 1, April 2015, hlm. 27-31.

[6] Hidayat, B. (2016). Analisis Keterlaksanaan Program Perkuliahan Micro teaching Berbasis Lesson Study Di Program Studi Pendidikan Sejarah FKIP UM Metro.Historia: Journal Of Teaching History And Historical Science, 4(2), 75-80. (Online). Sumber: https://media.neliti.com/media/publications/90073-ID-analisis-keterlaksanaan-programperkulia.pdf.

[7] Hindriana, A.F., \& Setiawati, Ina. (2018). The Development Of Autentik Assessment Rubric For Assessing Undergraduate Students Learning And Performance. Indonesian Journal of Learning and Instruction Vol.1 Issue 2 Oktober 2018. 
[8] Meltzer, D.E. (2002). The relationship between mathematics Preparation and Conceptual Laearning Grains in Physics: A Possible "Hidden variable" in Diagnostice Pretes Scores. American Journal Physics, Vol 70 (12), 27 Halaman. tersedia: www.iop.org/journal/physed.

[9] Mulyasa, E. (2007). Standar Kompetensi dan Sertifikasi Guru. Bandung: PT Remaja Rosdakarya.

[10] Nurlaelah, Ilah., Handayani., \& Setiawati, Ina. (2013). Analisis Profil Kompetensi Guru Pada Mahasiswa Calon Guru Biologi Di Universitas Kuningan Dan Upaya Perbaikannya. Jurnal Edubiologica Pascasarjana UNIKU.

[11] Nurlaelah, Ilah., Handayani., Setiawati, Ina. (2017). Perkembangan CalonGuru Profesional yang berfokus pada Pedagogical Content Knowledge (PCK) Pada Kelas Akademik Atas dan Akademik Bawah di Universitas Kuningan. Prosiding Seminar Nasional Pendidikan Sain II. Fakultas Biologi Universitas Kristen Satya Wacana. ISBN 978-602-61913-004.

[12] Putri, Agustiany Dumeva. (2018). Profil Kompetensi Pedagogik Calon Guru Matematika Melalui Lesson Study Pada Mata Kuliah Micro Teaching. Jurnal Pendidikan Matematika RAFA. Volume 4 $\begin{array}{lllll}\text { Nomor } & 1 & \text { Juni } & 2018 . & \text { (online). }\end{array}$ http://jurnal.radenfatah.ac.id/index.php/jpmrafa/article/view/2346

[13] Rejeki, Sri., Humaira, Maryani, Sri., Nizar. (2018). Lesson Study For Learning Community (LSLC): Pengalaman Berharga Dalam Pengelolaan Pembelajaran Secara Terbuka. Inopendas Jurnal Ilmiah Kependidikan ISSN 2615-5443 Vol. 1 No. 1, Februari 2018 Hal. 54-60

[14] Setiawati, I., \& Hindriana, A.F. (2020). Pengembangan asesmen kompetensi pedagogik pada mahasiswa calon guru biologi. JPBIO (Jurnal Pendidikan Biologi), 5(1), 1-11. DOI: 10.31932/jpbio.v5i1.531

[15] Widodo, Ari., Riandi., Ruswandi, Hermawan., Tatang, Herman. (2009). Peranan Lesson Study Dalam Meningkatkan Kemampuan Mengajar Guru Sekolah Dasar. Laporan Penelitian. UPI 